\title{
Effects of dietary energy and starch concentrations for newly received feedlot calves: I. Growth performance and health ${ }^{1,2}$
}

\author{
B. A. Berry ${ }^{* 3}$, C. R. Krehbiel ${ }^{* 4}$, A. W. Confer†, D. R. Gill*, \\ R. A. Smith + , and M. Montelongo $\dagger$ \\ Departments of *Animal Science, $\uparrow$ Veterinary Pathobiology, and \\ $\ddagger$ Veterinary Medicine Outreach, Oklahoma State University, Stillwater 74078
}

\begin{abstract}
Crossbred calves $(\mathrm{n}=572$; initial BW = $186 \pm 27 \mathrm{~kg}$ ) purchased from northern Texas, Arkansas, and southeast Oklahoma auction markets were delivered to the Willard Sparks Beef Research Center, Stillwater, OK, and used to study the effects of dietary energy and starch concentrations on performance and health of newly received feedlot calves during a 42 $\mathrm{d}$ receiving period. On arrival, calves were assigned randomly to one of two dietary energy levels $(0.85$ or 1.07 Mcal NE $/ \mathrm{kg} \mathrm{DM}$ ) and one of two dietary starch levels ( 34 or $48 \%$ of ME from starch) in a $2 \times 2$ factorial arrangement of treatments. Cattle were weighed and serum samples were collected on d $0,7,14,28$, and 42 . Individual animal records of morbidity were kept for all cases of respiratory and other disease. Nasal swabs were collected from each morbid animal and cultured for upper-respiratory pathogens. There were no energy $\times$ starch level interactions for performance or health response variables. Daily gain $(1.14 \mathrm{~kg} / \mathrm{d})$ and gain efficiency (ADG:DMI $=0.179$ ) were not affected by increasing dietary energy or starch concentrations. Calves fed low-energy diets consumed $(P<0.05)$ more DM. No difference $(P=0.54)$ was detected in morbidity for calves
\end{abstract}

fed high-energy (62.4\% calves treated) compared with low-energy ( $65.8 \%$ calves treated) diets; however, calves fed the high-starch diets had numerically $(P=0.11)$ greater morbidity than calves fed low-starch diets $(68.8$ vs. $59.4 \%$ calves treated, respectively). There were no energy or starch effects on Mannheimia haemolytica or Pasteurella multocida antibody titers; however, day effects $(P<0.02)$ occurred. On d 7, 14, and 28, calves had antibody titers for $P$. multocida that were greater $(P<0.05)$ than titers on $\mathrm{d} 0$. In addition, calves had greater antibody titers to $M$. haemolytica on $\mathrm{d} 7$ and 14 than on $d 0$. Nasal swabs revealed that calves fed the high-energy diets tended $(P=0.06)$ to have a lower percentage of morbid calves with $P$. multocida during the first antimicrobial treatment and a lower percentage of Haemophilus somnus isolates during the first $(P=0.01)$ and second $(P=0.06)$ antimicrobial treatments than calves fed the low-energy diets. Although animal performance was not influenced, the present data suggest that feeding the high-energy diet decreased the percentage of $P$. multocida and $H$. somnus pathogens in calves that received one or more antimicrobial treatments.

Key Words: Calves, Energy, Starch, Stress

(C)2004 American Society of Animal Science. All rights reserved.

J. Anim. Sci. 2004. 82:837-844

\section{Introduction}

Calves often arrive at feed yards after being marketed through one or more auction markets and traveling long distances. Stress at marketing is compounded by new feeds, noises, commingling, processing, and other factors on arrival at the feed yard (Galyean et al., 1999).

\footnotetext{
${ }^{1}$ Approved for publication by the director of the Oklahoma Agric. Exp. Stn. This research was supported under project H-2438.

${ }^{2}$ Appreciation is expressed to R. Ball and B. Starr from the Willard Sparks Beef Research Center for providing processing, animal care, and record-keeping expertise; Mizac Cattle Co., Purcell, OK, for providing cattle; and J. Summers and G. Meredith for help with laboratory analyses.
}

Diets must be formulated to supply adequate nutrients so that the calf does not rely on body stores, and to aid the calf in mounting an immune response to pathogens and vaccines. This is often difficult because of the low feed intake associated with lightweight stressed calves (Cole, 1996).

Increasing the concentration of nutrients in receiving diets seems logical for supplying calves with adequate

\footnotetext{
${ }^{3}$ Current address: Nutrition Service Associates, 310 Miles Ave., Hereford, TX 79045.

${ }^{4}$ Correspondence: 208 Anim. Sci. Bldg. (phone: 405-744-8857; fax: 405-744-7390; e-mail: kclinto@okstate.edu).

Received June 30, 2003.

Accepted October 31, 2003.
} 
Table 1. Background information regarding calves received at Willard Sparks Beef Research Center for this experiment

\begin{tabular}{lllccc}
\hline \hline $\begin{array}{l}\text { Group } \\
\text { No. }\end{array}$ & \multicolumn{1}{c}{ Origin } & Date received & $\begin{array}{c}\text { No. of } \\
\text { calves }^{\text {a }}\end{array}$ & $\begin{array}{c}\text { No. of } \\
\text { bulls/steers }\end{array}$ & $\begin{array}{c}\text { Initial } \\
\text { weight, kg }\end{array}$ \\
\hline 1 & Texas-Oklahoma-Arkansas & November 14, 2000 & 231 & $143 / 88$ & $189 \pm 14$ \\
2 & Texas-Oklahoma-Arkansas & January 21, 2001 & 167 & $93 / 74$ & $226 \pm 16$ \\
3 & Texas-Oklahoma-Arkansas & September 8, 2001 & 96 & $56 / 40$ & $173 \pm 14$ \\
4 & Texas-Oklahoma-Arkansas & September 15, 2001 & 78 & $48 / 30$ & $159 \pm 11$ \\
\hline
\end{tabular}

aTotal calves received $=572$. Twenty-four calves were removed from the study due to mortality or animal welfare issues not related to dietary treatments.

${ }^{b}$ Values are means \pm standard deviation.

nutrients and returning calves to a positive energy balance. However, high-energy diets are often made up of readily fermentable carbohydrate that may further stress the calves, making them more susceptible to health problems. Lofgreen et al. (1975) conducted experiments to determine the effects of increasing energy levels $(0.84,1.01,1.10$, and $1.19 \mathrm{Mcal} \mathrm{NE} / \mathrm{kg}$ of $\mathrm{DM})$ on the health and performance of stressed calves. They reported that the number of medical treatments per calf increased as the energy density of the diet increased. More recently, Fluharty and Loerch (1996) fed calves four dietary energy concentrations $(1.15,1.21$,

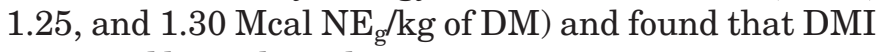
increased linearly with increasing energy concentration but found no overall differences in $\mathrm{ADG}$ or feed efficiency. Morbidity rate was similar (30\%) for all energy levels fed (Fluharty and Loerch, 1996). No data could be found in the refereed literature relating the starch content of diets to the health status of receiving calves. Low-starch by-products may offer alternatives to corn for formulating high-energy receiving diets. Therefore, the purpose of this experiment was to determine the effects of energy concentration in diets with two levels of starch on the performance and health of newly received calves.

\section{Materials and Methods}

Five hundred seventy-two auction-origin crossbred bull and steer calves (initial BW $=186 \pm 27 \mathrm{~kg}$ ) were received at the Willard Sparks Beef Research Center (WSBRC), Stillwater, OK, from November 2000 through September 2001 (Table 1). Calves were purchased from numerous auction markets in Oklahoma, Texas, or Arkansas, assembled in Purcell, OK (205 km from the WSBRC; Groups 1 and 2), or Texarkana, TX (514 km from the WSBRC; Groups 3 and 4), and shipped to the WSBRC. On arrival, calves were allowed to rest for approximately $1 \mathrm{~h}$ before pretrial $(\mathrm{d}-1)$ processing. Pretrial processing included a visual assessment of overall health, determination of sex, individual weighing of calves, and individually identifying each calf with a sequentially numbered ear tag. Calves were then distributed to holding pens, where they were given $1.0 \mathrm{~kg}$ of prairie hay per calf and ad libitum access to water. Approximately $16 \mathrm{~h}$ later, calves were processed.
Processing (d 0) included individual weight; vaccination for infectious bovine rhinotracheitis/parainfluenza-3 virus/bovine viral diarrhea/bovine respiratory syncytial virus (Frontier 4 Plus [Intervet, Millsboro, DE], $2 \mathrm{~mL}$ s.c.); vaccination for clostridial organisms (Covexin 8 [Schering-Plough, Omaha, NE], $5 \mathrm{~mL}$ s.c.); and treatment with anthelmintics for control of internal and external parasites (Ivomec-Plus [Merial Animal Health, Duluth, GA], $1.0 \mathrm{~mL} / 45.4 \mathrm{~kg}$ of BW s.c.). Bulls were left intact until after d 42 of the receiving period because of the potential elevation of acute-phase proteins associated with tissue damage. Acute phase protein data were reported by Berry et al. (2004) in the companion manuscript. Calves were revaccinated with viral respiratory vaccine on d 14. All procedures were in accordance with Oklahoma State University Animal Care and Use Guidelines.

On d 0, calves were sorted by corresponding sex (bull or steer) to provide each pen with an approximately equal number of bulls. Within each sex, calves were randomly assigned to pens to create approximately equal average pen weights using a random number table (Steel and Torrie, 1980). Each pen was then randomly assigned to one of four dietary treatments. Dietary treatments (Table 2) included two dietary energy (0.85 or $1.07 \mathrm{Mcal} \mathrm{NE}_{\mathrm{g}} / \mathrm{kg}$ of feed, DM basis) and two dietary starch (34 or $48 \%$ of dietary ME from starch) concentrations calculated using NRC (1996). All diets were formulated to meet or exceed NRC (1996) nutrient recommendations. The protein content of experimental diets was balanced to provide adequate degradable intake protein for microbial growth, whereas by-products used to create low-starch diets did not allow for balanced CP. Group 1 (Table 1) comprised two truckloads; calves were commingled and assigned to eight pens (two replicates/treatment; 28 or 29 calves/pen). Truckloads three and four (Group 2) were commingled and assigned to 12 pens (three replicates/treatment; 13 or 14 calves/ pen). Truckload five (Group 3; eight calves/pen) was assigned to twelve pens (three replicates/treatment) and truckload six (Group 4; 9 or 10 calves/pen) was assigned to eight pens (two replicates/treatment). The number of calves per pen was reduced following Group 1 due to inclement weather resulting in poor pen conditions. 
Table 2. Experimental diets (DM basis)

\begin{tabular}{|c|c|c|c|c|}
\hline \multirow[b]{2}{*}{ Item } & \multicolumn{2}{|c|}{ Low energy } & \multicolumn{2}{|c|}{ High energy } \\
\hline & Low starch & High starch & Low starch & High starch \\
\hline \multicolumn{5}{|l|}{ Ingredient, $\%$ of diet } \\
\hline Alfalfa hay—midbloom & 10.0 & 10.0 & 17.5 & 17.5 \\
\hline Cottonseed hulls & 35.0 & 35.0 & 17.5 & 17.5 \\
\hline Cracked corn & 13.0 & 24.5 & 22.1 & 37.5 \\
\hline Corn distillers grain ${ }^{a}$ & 12.8 & 6.5 & 19.5 & 9.9 \\
\hline Soybean hulls & 10.0 & 1.0 & 14.4 & 5.6 \\
\hline Wheat middlings & 10.36 & 12.96 & 0.76 & 0.86 \\
\hline Cottonseed meal & 1.5 & 2.0 & 1.0 & 6.5 \\
\hline Soybean meal, $47.7 \%$ & 6.3 & 7.0 & 6.1 & 3.4 \\
\hline Limestone, $38 \%$ & 0.80 & 0.80 & 0.90 & 1.00 \\
\hline Salt & 0.20 & 0.20 & 0.20 & 0.20 \\
\hline Other $^{\mathrm{b}}$ & 0.04 & 0.04 & 0.04 & 0.04 \\
\hline \multicolumn{5}{|l|}{ Nutrient composition } \\
\hline DM, $\%$ & 89.6 & 89.4 & 89.5 & 89.2 \\
\hline $\mathrm{ME}, \mathrm{Mcal} / \mathrm{kg}^{\mathrm{c}}$ & 2.34 & 2.36 & 2.60 & 2.61 \\
\hline $\mathrm{NE}_{\mathrm{m}}, \mathrm{Mcal} / \mathrm{kg}^{\mathrm{c}}$ & 1.45 & 1.47 & 1.68 & 1.69 \\
\hline $\mathrm{NE}_{\mathrm{g}}, \mathrm{Mcal} / \mathrm{kg}^{\mathrm{c}}$ & 0.85 & 0.86 & 1.07 & 1.07 \\
\hline $\mathrm{OM}, \%$ & 89.3 & 89.3 & 88.3 & 89.0 \\
\hline $\mathrm{CP}, \%$ & 16.2 & 15.2 & 17.4 & 16.5 \\
\hline DIP, $\mathrm{g} / \mathrm{kg}$ & 95.6 & 91.8 & 92.7 & 94.7 \\
\hline Starch, \% & 18.8 & 26.9 & 23.6 & 32.3 \\
\hline ME from starch, $\%^{\mathrm{c}}$ & 32 & 46 & 36 & 50 \\
\hline $\mathrm{NDF}, \%$ & 66.5 & 67.0 & 62.9 & 64.7 \\
\hline $\mathrm{ADF}, \%$ & 39.2 & 35.1 & 32.9 & 29.8 \\
\hline
\end{tabular}

${ }^{a}$ Dried corn distillers grains without solubles.

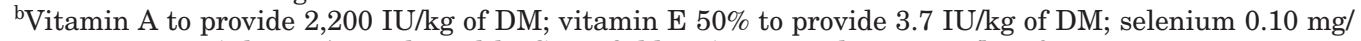
kg; Rumensin 80 (Elanco Animal Health, Greenfield, IN) to provide $27.5 \mathrm{mg} / \mathrm{kg}$ of monensin.

${ }^{\mathrm{c}}$ Calculated using NRC (1996).

Following d-0 processing, calves were moved to assigned pens $(12.2 \mathrm{~m} \times 30.5 \mathrm{~m})$ and offered $1.4 \mathrm{~kg}$ of their appropriate experimental diet. Feed was delivered into concrete fence-line feed bunks $(12.2 \mathrm{~m}$ of linear bunk space per pen). Prairie hay $\left(1.8 \mathrm{~kg} \cdot \mathrm{calf}^{-1} \cdot \mathrm{d}^{-1}\right)$ was supplied for the initial 2 to $5 \mathrm{~d}$ of the receiving period and decreased as the intake of experimental rations increased. Water was provided ad libitum via automatic water basins positioned to supply water to two adjacent pens per basin. Feed bunks were evaluated at approximately 0630 and 1830 for remaining feed, and feed delivery was adjusted before the 0630 feeding. Feed offered was increased by $0.23 \mathrm{~kg} \cdot \mathrm{calf}^{-1} \cdot \mathrm{d}^{-1}$ when a bunk was slick. Feed was weighed into individual containers on a platform scale and delivered twice daily at 0700 and 1300.

Calves were weighed on $\mathrm{d} 0,7,14,28$, and 42 of the experiment. All weights with the exception of $d-1$ and d 42 were shrunk by $4 \%$ to calculate daily gain and feed efficiency. On d 41, calves received morning feed only and the water was turned off at approximately 1700 before weighing the following morning (approximately 0700). Due to cold weather (colder than $-6^{\circ} \mathrm{C}$ ), calves from Group 2 were not shrunk on d 41 and, therefore, received a 4\% calculated shrink. For Groups 2 and 4, blood samples were collected (10-mL Vacutainer tubes with no additive) on d $0,7,14$, and 28 via jugular venipuncture from a random subset $(\mathrm{n}=6$ calves/pen) of calves from each treatment and allowed to equilibrate to ambient temperature before overnight storage at $4^{\circ} \mathrm{C}$. Serum was separated the following day and stored at $-10^{\circ} \mathrm{C}$ until laboratory analysis could be conducted.

Before feeding each morning, calves were evaluated in their pen by experienced personnel for signs of respiratory and other diseases. Each calf was given a severity score: 0) normal, 1) mild, 2) moderate, 3) severe, or 4) mortally ill. An animal was designated as morbid and transferred to the processing facility if it was scored as "severe" or if it was scored as "moderate" and exhibited two or more clinical signs of disease, including depression, lack of fill compared with pen mates, cough, altered gait, ocular or nasal discharge, or general physical weakness. On entry to the treatment facility, morbid calves were restrained in a hydraulic squeeze chute, and BW, rectal temperature, and a severity score were recorded. If the rectal temperature was $40^{\circ} \mathrm{C}$ or greater, a predetermined therapeutic antimicrobial regimen was initiated (Carter et al., 2002). In addition, one nasal swab was collected to determine the prevalence of upper-respiratory bacterial pathogens. Following treatment, calves were returned to their home pen. Nasal swabs were stored overnight at $4^{\circ} \mathrm{C}$ until they could be transported to the Oklahoma Animal Disease Diagnostic Laboratory the following morning for culture. Nasal swabs were plated on blood agar plates and examined by laboratory personnel at 24 and $48 \mathrm{~h}$ for growth of Mannheimia haemolytica, Pasteurella multocida, and Haemophilus somnus. Regardless of antimicrobial 
treatment, all information was recorded on individual sick cards and filed for future reference. If a calf was scored as slight or moderate and the rectal temperature was less than $40^{\circ} \mathrm{C}$, all information was recorded, and the calf was returned to its home pen without antimicrobial treatment.

Serum antibody concentrations to $M$. haemolytica and $P$. multocida were determined by enzyme-linked immunosorbent assay (ELISA; Confer et al., 1996; 1997). Enzyme-linked immunosorbent assay wells were coated with $100 \mu \mathrm{L}$ of antigen at a concentration of $1 \mathrm{ng} /$ $\mu \mathrm{L}$ of coating buffer for $P$. multocida outer-membrane proteins (OMP) and 1.850 optical density at $650 \mathrm{~nm}$ in $0.4 \%$ formalized PBS for $M$. haemolytica whole cells (WC). Plates were covered and rocked overnight in an incubator at $37^{\circ} \mathrm{C}$. The following day, plates were washed ( $3 \times)$ and dried prior to addition of sample. Standard and test samples were diluted in PBS-Tween201\% BSA (OMP, 1:400; WC, 1:800), $100 \mu \mathrm{L} /$ well was added and the plates were covered and incubated on a rocker for $1.5 \mathrm{~h}$ at $37^{\circ} \mathrm{C}$. Plates were again washed $(3 \times)$ with PBS-Tween20 and dried. A dilute (1:400 in PBSTween20-1\% BSA anti-bovine IgG) conjugated secondary antibody was added ( $100 \mu \mathrm{L} /$ well) and plates were incubated as before. Following a final wash (6×), 100 $\mu \mathrm{L} /$ well of a color substrate consisting of $O$-phenylenediamine and hydrogen peroxide was added to each well. Plates were allowed to color for approximately $5 \mathrm{~min}$ prior to a stop reagent being added. Optical density $\left(\mathrm{OD}_{490}\right)$ was determined for each plate in an automated plate reader (V Max Kinetic Microplate Reader, Molecular Devices, Inc.).

Feed samples were collected weekly and combined by receiving period subsequent to the experiment. Analysis (Table 2) included \% DM and OM (AOAC, 1996), $\mathrm{N} \times 6.25$ concentration analysis by combustion (Leco, NS2000, St. Joseph, MI), partitioning of nitrogen into degradable (DIP) and undegradable (UIP) intake protein utilizing the method of Roe et al. (1991), evaluation of starch concentration (Galyean, 1997), and separation of fiber into cell wall and cell content portions by NDF analysis and further separating hemicellulose from cellulose and lignin by $\mathrm{ADF}$ analysis (Van Soest et al., 1991).

Data were analyzed using the Mixed procedure of SAS (SAS Institute Inc., Cary, NC). Pen was used as the experimental unit for all data. The experiment was designed as a randomized complete block, blocked by group, with a $2 \times 2$ factorial treatment structure. Main effects were two levels of energy and two levels of ME contribution from starch. Two-way interactions between main effects and block were tested. Group $\times$ starch and group $\times$ energy interaction terms were not significant and were removed from the model. The three-way interaction between main effects and block (group) was used as the overall error term $\left(\delta_{\mathrm{e}}{ }^{2}\right)$ and used to test main effects. Calves were assigned to pens such that each pen would have approximately the same number of bulls in order to minimize sex effects. For nonparametric variables related to health, such as number of antimicrobial treatments and upper respiratory pathogens, data were transformed using Friedman's test, and then analyzed as normally distributed data as above (Elam et al., 2003). Antibody titers were analyzed as a randomized complete block design with repeated measures over days; the model included fixed effects of energy, starch, days, and the appropriate twoway and three-way interactions (Littell et al., 1998). Data were repeated over days, and the proper covariance structure (autoregressive [1]) was determined. Results are discussed as significant if $P \leq 0.05$ and as tendencies if $P \leq 0.06$ to $P \leq 0.10$.

\section{Results and Discussion}

Animal Performance. Feedlot performance data are shown in Table 3. Twenty-four calves were removed from the study due to mortality (pneumonia, $\mathrm{n}=3$ ) or animal welfare issues (crippled, $\mathrm{n}=16$; polioencephalomalacia, $\mathrm{n}=1$; preexisting respiratory disease, $\mathrm{n}=2$; refusal to eat, $n=2$ ). Due to the low death loss, mortality data was not analyzed. Daily gain and gain efficiency (ADG:DMI) were not affected $(P<0.15)$ by dietary energy or starch concentrations. Overall, calves gained similarly, averaging $1.14 \pm 0.12 \mathrm{~kg} \cdot \mathrm{calf}^{-1} \cdot \mathrm{d}^{-1}$. Similarly, Ohio researchers (Fluharty and Loerch, 1996) fed four dietary $\mathrm{NE}_{\mathrm{g}}$ levels $(1.15,1.21,1.25$, and $1.30 \mathrm{Mcal} / \mathrm{kg}$ of DM) to stressed calves and found no energy effects on daily gain or feed efficiency. In contrast, Lofgreen et al. (1975) reported a linear increase in the daily gain of stressed calves fed $0.84,1.01$, or $1.10 \mathrm{Mcal} \mathrm{NE} / \mathrm{kg}$ of DM as dietary energy levels increased. In our experiment, dietary starch level had no effect $(P<0.28)$ on either overall or interval period DMI. Calves fed lowenergy diets consumed more $(P<0.05 ; 3.7 \%)$ DM than calves fed high-energy diets during the overall feeding period. However, this difference did not affect feed efficiency. These differences are in contrast to previously reported experiments (Fluharty and Loerch, 1996; Lofgreen et al., 1975) that reported increasing DMI as dietary $\mathrm{NE}_{\mathrm{g}}$ levels increased. Similar to previous studies (Fluharty and Loerch, 1996; Lofgreen et al., 1975), during the critical initial week of the receiving period when intake is typically very low, intake was similar for all diets. Mean DMI for all groups was approximately $2.8 \pm 0.5 \mathrm{~kg}$ ( $1.5 \%$ of initial BW) during the first week and $5.5 \pm 0.6 \mathrm{~kg}$ for the entire 42 -d receiving period.

Estimated $(1.08 \mathrm{~kg} / \mathrm{d})$ and actual $(1.12 \mathrm{~kg} / \mathrm{d})$ gains were similar for calves consuming high-energy diets. However, calves fed diets calculated to provide 0.85 $\mathrm{Mcal} / \mathrm{kg}$ of DM gained $141 \%$ of estimated gain for the high-starch diet and $148 \%$ of estimated gain for the low-starch diet. These deviations from expected performance may be partly explained by the increased intake of calves consuming the low-energy diets. One may speculate that calves fed the low-energy diets gained an intake advantage over calves fed high-energy diets 
Table 3. Effects of energy and starch level on receiving period performance by calves fed for $42 \mathrm{~d}$

\begin{tabular}{|c|c|c|c|c|c|c|c|c|}
\hline \multirow[b]{2}{*}{ Item } & \multicolumn{2}{|c|}{ Low energy } & \multicolumn{2}{|c|}{ High energy } & \multirow[b]{2}{*}{ SEM $^{\mathrm{a}}$} & \multicolumn{3}{|c|}{ Probability $>$ F } \\
\hline & $\begin{array}{l}\text { Low } \\
\text { starch }\end{array}$ & $\begin{array}{l}\text { High } \\
\text { starch }\end{array}$ & $\begin{array}{c}\text { Low } \\
\text { starch }\end{array}$ & $\begin{array}{l}\text { High } \\
\text { starch }\end{array}$ & & Starch & Energy & $\begin{array}{c}\text { Starch } \times \\
\text { Energy }\end{array}$ \\
\hline Pens (calves) & 10 (138) & 10 (140) & 10 (134) & 10 (136) & - & - & - & - \\
\hline \multicolumn{9}{|l|}{ Weight, kg } \\
\hline d 0 & 187 & 185 & 188 & 188 & 14.2 & 0.75 & 0.28 & 0.41 \\
\hline d 42 & 236 & 234 & 236 & 235 & 18.4 & 0.63 & 0.99 & 0.67 \\
\hline \multicolumn{9}{|l|}{$\mathrm{ADG}, \mathrm{kg}$} \\
\hline d 0 to 7 & -0.23 & -0.11 & -0.37 & -0.23 & 0.31 & 0.65 & 0.55 & 0.97 \\
\hline d 8 to 14 & 0.89 & 1.09 & 1.08 & 0.88 & 0.53 & 0.99 & 0.97 & 0.32 \\
\hline d 15 to 28 & 1.72 & 1.66 & 1.60 & 1.60 & 0.24 & 0.79 & 0.52 & 0.77 \\
\hline d 29 to 42 & 1.41 & 1.25 & 1.47 & 1.35 & 0.24 & 0.26 & 0.39 & 0.83 \\
\hline d 0 to 42 & 1.17 & 1.14 & 1.14 & 1.10 & 0.12 & 0.71 & 0.51 & 0.83 \\
\hline \multicolumn{9}{|l|}{ DMI, kg/d } \\
\hline d 0 to 7 & 2.8 & 2.8 & 2.7 & 2.8 & 0.48 & 0.52 & 0.50 & 0.58 \\
\hline d 8 to 14 & 4.6 & 4.5 & 4.3 & 4.3 & 0.53 & 0.74 & 0.09 & 0.64 \\
\hline d 15 to 28 & 5.8 & 5.8 & 5.6 & 5.6 & 0.42 & 0.74 & 0.09 & 0.86 \\
\hline d 29 to 42 & 7.5 & 7.4 & 7.2 & 6.9 & 1.11 & 0.28 & 0.08 & 0.50 \\
\hline d 0 to 42 & 5.6 & 5.6 & 5.4 & 5.3 & 0.63 & 0.63 & 0.05 & 0.86 \\
\hline \multicolumn{9}{|l|}{ Gain:feed } \\
\hline d 0 to 7 & -0.151 & -0.045 & -0.188 & -0.142 & 0.152 & 0.67 & 0.56 & 0.79 \\
\hline d 8 to 14 & 0.166 & 0.237 & 0.235 & 0.190 & 0.133 & 0.81 & 0.86 & 0.21 \\
\hline d 15 to 28 & 0.304 & 0.291 & 0.288 & 0.285 & 0.044 & 0.70 & 0.74 & 0.82 \\
\hline d 29 to 42 & 0.203 & 0.184 & 0.212 & 0.211 & 0.049 & 0.38 & 0.16 & 0.41 \\
\hline d 0 to 42 & 0.209 & 0.209 & 0.214 & 0.208 & 0.017 & 0.86 & 0.88 & 0.73 \\
\hline
\end{tabular}

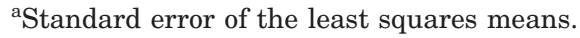

due to the form of added roughage (i.e., cottonseed hulls) in the low-energy diets. The increased roughage might have resulted in a positive associative effect by slowing the passage rate of fermentable carbohydrates and increasing digestible energy, thereby increasing NE values of the diets. It is also plausible that the deviance of observed gain from expected gain was due to increased gut fill in calves fed the less-concentrated diets. In contrast to the present study, Lofgreen et al. (1975) reported that stressed, newly received calves generally consume greater quantities of higher-concentrate diets.

The $\mathrm{NE}_{\mathrm{g}}$ of diets was calculated using equations established by Lofgreen and Garrett (1968). These calculations illustrated the reliance of $\mathrm{NE}_{\mathrm{g}}$ on intake. Calves fed low-energy diets consumed more DM and gained similarly to calves fed high-energy diets. Thus, when the $\mathrm{NE}_{\mathrm{g}}$ of individual diets were calculated from retained energy and compared, all diets were similar (1.18 $\mathrm{Mcal} / \mathrm{kg}$ ), with the exception of the low-starch, low-energy diet $(1.41 \mathrm{Mcal} / \mathrm{kg}$ ), which had a greater calculated $\mathrm{NE}_{\mathrm{g}}$ concentration compared with all other diets.

Overall, total mixed ration CP values were high compared with calculated values from reference feeds used to formulate the experimental diets (NRC, 1996). Although the metabolizable protein (MP) concentration differed among treatment groups, calves were not limited by protein in any of the experimental diets. Based on NRC (1996) equations, MP available for gain exceeded the calculated MP requirement for gain by 138 , 114,212 , and $185 \mathrm{~g} / \mathrm{d}$ for calves fed, respectively, diets of low energy, low starch; low energy, high starch; high energy, low starch; and high energy, high starch. Regardless of diet, calves appeared to be limited by energy intake rather than protein intake. Effects of varying protein levels in receiving diets have been characterized. Galyean et al. (1993) reported increased ADG with increasing supplemental soybean meal fed to $185-\mathrm{kg}$ calves in a 42-d receiving study. Similarly, Ohio researchers (Fluharty and Loerch, 1995) assessed protein requirements of newly received calves by feeding 12 , 14,16 , or $18 \% \mathrm{CP}$ diets and reported a linear increase in ADG for the first week after arrival. In a second experiment, these researchers fed 11, 14, 17, 20,23, or $26 \%$ CP diets. Daily gain and gain efficiency increased quadratically, with the $20 \% \mathrm{CP}$ diet resulting in the greatest performance. Eck et al. (1988) conducted a series of 28-d trials to evaluate protein concentration for incoming feeder calves. In their experiment, calves were fed steam-flaked sorghum grain-based diets consisting of either 10.5 or $12.5 \%$ dietary CP. Calves fed the $12.5 \% \mathrm{CP}$ diet had greater $\mathrm{ADG}$ and were more efficient than calves fed the $10.5 \%$ CP diet.

Health Performance. Health performance data for calves from Group 1 was omitted from analysis because of an electronic thermometer malfunction, which was not detected until late in the receiving period. Sixtyfour percent of calves across all treatments received at least one antimicrobial treatment, and 28 and $6.2 \%$ of calves treated required a second and third treatment, respectively (Table 4). Calves fed the high-starch diets had a numerically $(P=0.11)$ greater percentage of calves receiving the first antimicrobial treatment, and 
Table 4. Effects of energy and starch level on health performance of calves during a 42$\mathrm{d}$ receiving period

\begin{tabular}{|c|c|c|c|c|c|c|c|c|}
\hline \multirow[b]{2}{*}{ Item } & \multicolumn{2}{|c|}{ Low energy } & \multicolumn{2}{|c|}{ High energy } & \multirow[b]{2}{*}{ SEM $^{\mathrm{a}}$} & \multicolumn{3}{|c|}{ Probability $>F$} \\
\hline & $\begin{array}{l}\text { Low } \\
\text { starch }\end{array}$ & $\begin{array}{l}\text { High } \\
\text { starch }\end{array}$ & $\begin{array}{c}\text { Low } \\
\text { starch }\end{array}$ & $\begin{array}{l}\text { High } \\
\text { starch }\end{array}$ & & Starch & Energy & $\begin{array}{c}\text { Starch } \times \\
\text { energy }\end{array}$ \\
\hline Pens (calves) ${ }^{b}$ & $8(86)$ & $8(85)$ & $8(86)$ & $8(84)$ & & & & \\
\hline Treated once, $\%$ & 64.9 & 66.7 & 53.8 & 70.9 & 13.9 & 0.11 & 0.54 & 0.18 \\
\hline d 1 to $7, \%$ & 61.8 & 61.1 & 50.8 & 59.4 & - & - & - & - \\
\hline d 8 to $42, \%$ & 38.2 & 38.9 & 49.2 & 40.6 & - & - & - & - \\
\hline Day treated & 3.9 & 4.7 & 4.6 & 5.8 & 1.94 & 0.07 & 0.09 & 0.62 \\
\hline Treated twice, $\%$ & 33.1 & 27.3 & 20.5 & 29.7 & 13.3 & 0.73 & 0.28 & 0.12 \\
\hline Day treated & 11.7 & 10.7 & 12.4 & 18.4 & 3.46 & 0.35 & 0.12 & 0.18 \\
\hline Treated thrice, $\%$ & 7.5 & 9.7 & 1.9 & 5.6 & 5.56 & 0.24 & 0.06 & 0.75 \\
\hline Day treated & 20.4 & 22.3 & 20.7 & 19.8 & 5.95 & 0.90 & 0.78 & 0.72 \\
\hline
\end{tabular}

astandard error of the least squares means.

${ }^{\mathrm{b}}$ Group 1 health data was omitted due to a malfunctioning thermometer; therefore, $\mathrm{n}=8$.

their first treatment tended $(P=0.07)$ to be $1 \mathrm{~d}$ later than calves fed the low-starch diets. No energy effects occurred $(P<0.12)$ for first or second treatments; however, calves fed the high-energy diets tended $(P=0.06)$ to have a lower percentage of animals treated with a third antimicrobial treatment compared with calves fed the low-energy diets. The present data are consistent with Fluharty and Loerch (1996), who reported similar incidences of respiratory disease for calves fed diets varying in $\mathrm{NE}_{\mathrm{g}}$ from 1.15 to 1.30 Mcal. In contrast, Lofgreen et al. (1975) reported that morbidity tended to increase with increasing dietary energy. However, results were inconsistent throughout their trials. In our experiment, the numeric trend $(P=0.11)$ due to starch level resulted primarily from the lower morbidity when high-energy, low-starch was fed, which suggests that starch content in high-energy diets might influence morbidity.

Serum Antibody Titers. No starch, energy, energy $\times$ starch, or energy $\times$ starch $\times$ day effects were detected for either M. haemolytica or P. multocida serum antibody titers. However, day effects were found for P. multocida $(P<0.001)$ and $M$. haemolytica $(P<0.02$; Table 5$)$. Calves developed antibody titers greater $(P<0.05)$ than initial (d 0) levels for both pathogens by d 7 and continued through d 28 for $P$. multocida and d 14 for $M$. haemolytica. No previous data could be found relating energy concentration or source to antibody titers for bovine respiratory disease complex pathogens. However, it appears from the present data that antibody titers to $P$. multocida and $M$. haemolytica increase as days on feed increase in newly received calves.

Upper Respiratory Pathogens. Mannheimia haemolytica was the most prevalent pathogen isolated from the upper respiratory tract of morbid calves and was detected in $78 \%$ of morbid calves at the time of first treatment, $42 \%$ at second treatment, and $27 \%$ at third treatment (Table 6). Calves fed the high-energy diets tended $(P=0.07)$ to have a lower incidence of $M$. haemolytica compared with calves fed the low-energy diets during the second antimicrobial treatment. Frank and Smith (1983) reported similar percentages of the incidence of $M$. haemolytica in feedlot calves treated for respiratory disease in one experiment, whereas incidence of $M$. haemolytica was nearly $100 \%$ in morbid calves in a second experiment. Prevalence of $P$. multocida in the upper respiratory tract of morbid calves measured at the first treatment tended $(P=0.06)$ to be lower for calves fed the high-energy diets, whereas starch level did not affect $(P<0.87)$ the prevalence of $P$. multocida. The presence of $H$. somnus in the nasal swabs of cattle treated for respiratory disease was generally low: 5.3\%

Table 5. Serum antibody toters to Pasteurella multocida and Mannheimia haemolytica during a $42-\mathrm{d}$ receiving period ${ }^{\mathrm{a}}$

\begin{tabular}{|c|c|c|c|c|c|c|}
\hline \multirow[b]{2}{*}{ Item } & \multicolumn{4}{|c|}{ Day of sampling } & \multirow[b]{2}{*}{$\mathrm{SEM}^{\mathrm{b}}$} & \multirow[b]{2}{*}{ Probability $>F$} \\
\hline & 0 & 7 & 14 & 28 & & \\
\hline Pens (calves) ${ }^{\mathrm{c}}$ & $5(30)$ & $5(30)$ & $5(30)$ & $5(30)$ & & \\
\hline P. multocida ${ }^{\mathrm{d}}$ & $0.97^{\mathrm{e}}$ & $1.20^{\mathrm{f}}$ & $1.35^{\mathrm{f}}$ & $1.30^{\mathrm{f}}$ & 0.08 & 0.001 \\
\hline M. haemolytica & $0.158^{\mathrm{e}}$ & $0.236^{\mathrm{f}}$ & $0.250^{\mathrm{f}}$ & $0.211^{\mathrm{ef}}$ & 0.084 & 0.02 \\
\hline
\end{tabular}

${ }^{\text {a }}$ Measured as nanograms of secondary antibody that bound to sample.

${ }^{\mathrm{b}}$ Standard error of the least squares means.

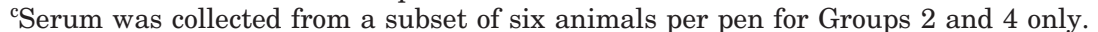

${ }^{\mathrm{d}}$ Measured by enzyme-linked immunosorbent assay to $P$. multocida outer membrane protein.

e,f Means in same row with different superscripts differ $(P<0.05)$.

${ }^{g}$ Measured by enzyme-linked immunosorbent assay to $M$. haemolytica whole cells. 
Table 6. Prevalence of pathogens in nasal cavity of calves treated with an antimicrobial compound

\begin{tabular}{|c|c|c|c|c|c|c|c|c|}
\hline \multirow[b]{3}{*}{ Item } & \multicolumn{2}{|c|}{ Low energy } & \multicolumn{2}{|c|}{ High energy } & \multirow[b]{3}{*}{$\mathrm{SEM}^{\mathrm{a}}$} & \multirow{2}{*}{\multicolumn{3}{|c|}{ Probability $>F$}} \\
\hline & \multirow{2}{*}{$\begin{array}{l}\text { Low } \\
\text { starch }\end{array}$} & \multirow{2}{*}{$\begin{array}{l}\text { High } \\
\text { starch }\end{array}$} & \multirow{2}{*}{$\begin{array}{l}\text { Low } \\
\text { starch }\end{array}$} & \multirow{2}{*}{$\begin{array}{l}\text { High } \\
\text { starch }\end{array}$} & & & & \\
\hline & & & & & & Starch & Energy & Starch $\times$ energy \\
\hline \multicolumn{9}{|l|}{ First treatment ${ }^{\mathrm{b}}$} \\
\hline M. haemolytica, \% & 83.8 & 78.2 & 77.3 & 71.6 & 16.9 & 0.44 & 0.38 & 0.99 \\
\hline P. multocida, $\%$ & 24.8 & 27.5 & 16.0 & 11.1 & 7.2 & 0.87 & 0.06 & 0.56 \\
\hline H. somnus, \% & 1.2 & 16.5 & 0.0 & 3.3 & 5.5 & 0.04 & 0.01 & 0.11 \\
\hline \multicolumn{9}{|l|}{ Second treatment ${ }^{c}$} \\
\hline M. haemolytica, $\%$ & 54.7 & 52.6 & 21.6 & 38.9 & 13.6 & 0.55 & 0.07 & 0.44 \\
\hline P. multocida, $\%$ & 10.5 & 23.8 & 32.3 & 4.1 & 15.6 & 0.54 & 0.93 & 0.09 \\
\hline H. somnus, \% & 7.2 & 13.7 & 0.0 & 0.0 & 12.0 & 0.86 & 0.06 & 0.31 \\
\hline \multicolumn{9}{|l|}{ Third treatment ${ }^{\mathrm{d}}$} \\
\hline M. haemolytica, $\%$ & 16.8 & 50.0 & 40.0 & 0.0 & 23.8 & 0.88 & 0.54 & 0.11 \\
\hline P. multocida, \% & 25.0 & 12.5 & 20.0 & 0.0 & 22.0 & 0.42 & 0.66 & 0.85 \\
\hline H. somnus, \% & 28.7 & 2.8 & 13.4 & 12.5 & 18.8 & 0.22 & 0.79 & 0.24 \\
\hline
\end{tabular}

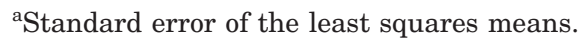

${ }^{\mathrm{b}}$ Percentage of calves having positive cultures for pathogen during first treatment (see Table 4 for number of observations).

${ }^{\mathrm{c} P e r c e n t a g e}$ of calves having positive cultures for pathogen during second treatment (see Table 4 for number of observations).

${ }^{\mathrm{d}}$ Percentage of calves having positive cultures for pathogen during third treatment (see Table 4 for number of observations).

during the first treatment, $5.2 \%$ in calves treated a second time, and $14.4 \%$ in calves treated a third time. Interestingly, the high-energy dietary treatment had a lower $(P=0.01)$ percentage of calves with $H$. somnus isolates at the initial treatment, and tended $(P=0.06)$ to have a lower percentage of $H$. somnus isolates at the second treatment compared with calves fed low-energy diets. During the initial treatment, there was a greater $(P=0.04)$ percentage of calves with $H$. somnus isolates when calves were fed the high-starch diets compared with calves fed the low-starch diets. This result was generally due to the greater percentage of $H$. somnus isolates in calves fed the low-energy, high-starch diet. No effect $(P<0.21)$ of energy or starch was found during the third treatment.

Data evaluating the effect of dietary nutrients on pathogens in the upper-respiratory tract in relation to the incidence of respiratory disease are limited. Although animal performance was not affected by dietary treatment, the present data suggest that feeding higher energy diets (1.07 vs. 0.86 Mcal of $\mathrm{NE}_{\mathrm{g}} / \mathrm{kg}$ of $\mathrm{DM}$ ) decreased the percentage of $P$. multocida and $H$. somnus pathogens in calves that received one or more antimicrobial treatments. Calories from starch appeared to be less of a factor, although calves fed high-starch diets (48 vs. $34 \mathrm{Mcal}$ or ME from starch) had a greater percentage of calves receiving an antimicrobial treatment, and a greater percentage of treated calves had isolates of $H$. somnus.

\section{Implications}

No adjustment to energy requirements for stressed calves has been established to date. Growth performance was not influenced by dietary energy or starch level in the present experiment, although calves fed low-energy diets tended to have greater feed intake. The present data suggest that feeding higher-energy diets decreases the percentage of calves with Pasteurella multocida and Haemophilus somnus pathogens in calves that receive one or more antimicrobial treatments. Further research into the effect of respiratory disease on energy requirements would provide useful information, allowing producers to formulate diets to meet the needs of newly received calves. A wider range of energy and starch concentrations than was fed in the present experiment should be examined to determine the upper limits of energy concentrations that should be fed to newly received feedlot calves.

\section{Literature Cited}

AOAC. 1996. Official Methods of Analysis. 16th ed. Assoc. Offic. Anal. Chem., Arlington, VA.

Berry, B. A., A. W. Confer, C. R. Krehbiel, D. R. Gill, R. A. Smith, and M. Montelongo. 2004. Effects of dietary energy and starch concentrations in newly received feedlot calves: II. Acute phase proteins. J. Anim. Sci. 82:845-850.

Carter, J. N., G. L. Meredith, M. Montelongo, D. R. Gill, C. R. Krehbiel, M. E. Payton, and A. W. Confer. 2002. Relationship of vitamin E supplementation and antimicrobial treatment with acute-phase protein response in cattle affected by naturally acquired respiratory tract disease. Am. J. Vet. Res. 63:1111-1117.

Cole, N. A. 1996. Review of bovine respiratory disease: Nutrition and disease interactions. Pages 57-74 in Review of Respiratory Disease-Schering-Plough Animal Health. R. A. Smith, ed. Veterinary Learning Systems, Trenton, NJ.

Confer, A. W., S. H. Nutt, S. M. Dabo, R. J. Panciera, and G. L. Murphy. 1996. Antibody responses of cattle to outer membrane proteins of Pasteurella multocida A:3. Am. J. Vet. Res. 57:1453-1457.

Confer, A. W., K. D. Clinkenbeard, D. M. Gatewood, B. A. Driskel, and M. Montelongo. 1997. Serum antibody responses of cattle 
vaccinated with partially purified native Pasteurella haemolytica leukotoxin. Vaccine 15:1423-1429.

Eck, T. P., S. J. Bartle, R. L. Preston, R. T. Brandt, Jr., and C. R. Richardson. 1988. Protein source and level for incoming feedlot cattle. J. Anim. Sci. 66:1871-1876.

Elam, N. A., J. F. Gleghorn, J. D. Rivera, M. L. Galyean, P. J. Defoor, M. M. Brashears, and S. M. Younts-Dahl. 2003. Effects of live cultures of Lactobacillus acidophilus (strains NP45 and NP51) and Propionibacterium freudenreichii on performance, carcass, and intestinal characteristics, and Escherichia coli 0157 shedding of finishing beef steers. J. Anim. Sci. 81:2686-2698.

Fluharty, F. L., and S. C. Loerch. 1995. Effects of protein concentration and protein source on performance of newly arrived feedlot steers. J. Anim. Sci. 73:1585-1594.

Fluharty, F. L., and S. C. Loerch. 1996. Effects of dietary energy source and level on performance of newly arrived feedlot calves. J. Anim. Sci. 74:504-513.

Frank, G. H., and P. C. Smith. 1983. Prevalence of Pasteurella haemolytica in transported calves. Am. J. Vet. Res. 44:981-985.

Galyean, M. L., S. A. Gunter, K. J. Malcolm-Callis, and D. R. Garcia. 1993. Effects of crude protein concentration in the receiving diet on performance and health of newly received beef calves. Clayton Livestock Res. Ctr. Prog. Rep. No. 88. NM Agric. Exp. Stn., Las Cruces.
Galyean, M. L. 1997. Laboratory Procedures in Animal Nutrition Research. Texas Tech Univ. Available: http://www.asft.ttu.edu/ home/mgalyean/lab_man.pdf. Accessed June 11, 2003.

Galyean, M. L., L. J. Perino, and G. C. Duff. 1999. Interaction of cattle health/immunity and nutrition. J. Anim. Sci. 77:11201134.

Littell, R. C., P. R. Henry, and C. B. Ammerman. 1998. Statistical analysis of repeated measures data using SAS procedures. J. Anim. Sci. 76:1216-1231.

Lofgreen, G. P., and W. N. Garrett. 1968. A system for expressing net energy requirements and feed values for growing and finishing cattle. J. Anim. Sci. 27:793-806.

Lofgreen, G. P., J. R. Dunbar, D. G. Addis, and J. G. Clark. 1975. Energy level in starting rations for calves subjected to marketing and shipping stress. J. Anim. Sci. 41:1256-1265.

NRC. 1996. Nutrient Requirements of Beef Cattle. Natl. Acad. Press, Washington, DC.

Roe, M. B., L. E. Chase, and C. J. Sniffen. 1991. Comparison of in vitro techniques to the in situ technique for estimation of ruminal degradation of protein. J. Dairy Sci. 74:1623-1631.

Steel, R. G. D., and J. H. Torrie, 1980. Principles and Procedures of Statistics: A Biometrical Approach. McGraw-Hill Book Co.

Van Soest, P. J., J. B. Robertson, and B. A. Lewis. 1991. Symposium: Carbohydrate methodology, metabolism and nutritional implications in dairy cattle. J. Dairy Sci. 74:3583-3597. 